\title{
Assertive training and family psychological education therapy on adolescents self-esteem in prevention of drug use in boarding school
}

\author{
Indah Ramadhan ${ }^{1}$, Budi Anna Keliat ${ }^{2 *}$, Ice Yulia Wardani ${ }^{2}$ \\ ${ }^{1}$ Postgraduate Programme Faculty of Nursing,Universitas Indonesia, Depok, West Java-16424 \\ ${ }^{2}$ Faculty of Nursing, Universitas Indonesia \\ *Corresponding author E-mail: budianna_keliat@yahoo.com
}

\begin{abstract}
Adolescents are prone to use drugs when they have low self-esteem. Assertiveness training and family psychological education therapies are mental health nursing specialist interventions that are expected to increase adolescent self esteem so that adolescent has ability to prevent drug use. This study aims to determine the effect of assertiveness training and family psychological education therapy on adolescent self-esteem in the prevention of drug use in boarding schools. The research design was a quasi-experimental pre-post test with a control group. Sixty four adolescent students at the boarding school were selected using purposive sampling technique and cluster random sampling. The intervention group 1 only received general nursing intervention and the intervention group 2 received general nursing intervention, assertiveness training, and family psychological education therapy. The results showed that the self-esteem of adolescent students increased significantly after receiving nursing intervention and in the high self-esteem category $(p=0.017)$, after assertiveness training and family psychological education therapy, adolescent self-esteem in the intervention group 2 increased greater than only general nursing intervention $(\mathrm{P}=0,000)$ with the high self-esteem category. There is the influence of assertiveness training and family psychological education therapy on adolescent self-esteem in prevention of drugs uses in a boarding school. Community health center is recommended to do nursing care in school through school health unit program either by primary care nurse or nurse specialist of mental health nursing.
\end{abstract}

Keywords: Assertiveness Training; Family Psychological Education Therapy; Self-Esteem; Drugs; Adolescent; Boarding Schools.

\section{Introduction}

Abuse of Narcotics, Psychotropic, and Other Addictive Substances (NAPZA) has become a health problem in adolescence. Adolescents in the world are estimated 1.2 billion or about $18 \%$ of the total population of the world and in Indonesia a group of 10-19 years old according to the 2010 population census is 43.5 million adolescents or about $18 \%$ of the total population (PusdatinKemenkes RI, 2015).The results of the National Narcotics Agency (BNN) research in collaboration with puslitkes UI in 2015 showed that the prevalence of abusers in a group of 10-19 years old increased from $0.7 \%$ (2010) to $0.9 \%$ (2015) and based on that number is at least 8000 elementary school students have been exposed to drugs (BNN RI, 2015). In general, the age of drug users ranges from 15 to 25 years and begins at age 10 years. Therefore, adolescents who have aged between 10-19 years old are vulnerable to drug use.

Adolescence is a stage of development that occurs between the ages of 11 to 20 years (Stuart, 2013). In general, adolescents face physical, cognitive, and emotional changes such as physical maturation, self-image, and closeness with group friends, identity search and tend to have autonomous attitudes. Changes that occur can cause pressure and generate a variety of responses that cause adolescents vulnerable to risk behavior such as drug use, suicide, violent behavior and bullying (James \&Ashwill, 2007; Stuart, 2013). Adolescents need a good self-concept to deal with those changes so that adolescents can reach maturity and go through that period.
Widodo (2009) mentions that the factors which cause adolescents to use drugs including internal factors and external factors. Internal factors include curiosity, to ease tension and anxiety, to gain new experiences, fill in boredom, unfulfilled expectations and ways to deal with problems. While the external factors that become common reasons for drug abuse include the invitation of peers, family environment, and school environment.

The feeling of low self-esteem may be the reasons why adolescents use drugs (Khajehdaluee, Zavar, Alidoust, and Pourandi, 2013; Stuart, 2013). Self-esteem is an individual's judgment of himself and relates to the success of adolescents in achieving the developmental task of finding self-identity. Self-esteem is a feeling of self-acceptance, unconditionally, albeit wrong, defeated, and failed, as a valuable and important trait. Self-esteem involves full responsibility for the life of the individual itself. The development of self-esteem in adolescents is an important thing to note because it can affect mental health and adolescent behavior in adulthood (Stuart, 2013; Sulistyowati and Warsito, 2010). Therefore, efforts to build and improve adolescent self-esteem need to be done so that adolescents are able to complete the task of its development well.

Swenson and Prelow (2005) suggest that individuals with high selfesteem will be able to resolve problems such as depression and juvenile delinquency. It is also supported by Asia (2008) which stated that self-esteem would contribute to adolescent attitudes, especially in daily life. Adolescents with low self-esteem tend to have a negative attitude in behaving and feeling unaccepted, under appreciated, and got poor treatment by others. The result of Hanana's (2015) 
study mentions that the categorization of low self-esteem in adolescent students was found to be $48.5 \%$ or 97 students and high selfesteem category of $51.5 \%$ or 103 boarding school students. This is because many factors that affect self-esteem, and adolescent factor become one of the factors that influence the level of self-esteem in boarding school students.

Wardana, Istiaji \& Ririanty (2015) stated that one of the Centers for Reproductive Health Information of Indonesian boarding school has said that there were once two boarding school students who were expelled from boarding school due to drug abuse in 2014 Drug prevention efforts at boarding school have been done through the training for teachers in boarding schools to prevent drug use among boarding school students and the surrounding environment (" Boarding School Teachers in Jakarta Learning Drug Prevention in Lido," 2008). Even some boarding schools in Indonesia have contributed to the provision of rehabilitation facilities for former drug users. Therefore, the prevention of drugs in adolescents, especially in boarding school students is very important in the eradication of drug in Indonesia so that none of the boarding school students use drugs in the future. Boarding schools need to work together with mental health nurses to provide learning in improving knowledge, moral, spiritual, and mental health for boarding school students.

Groups of boarding school students who have never used drugs are given primary prevention to increase adolescents self-esteem and prevent future drug use. Primary prevention is addressed to someone who previously did not use drugs to prevent not trying or using drugs (Pusdatin Kemenkes RI, 2014).

Assertive training which is a structured mental health nursing intervention can be used to promote equal and effective social relationships that enable individuals to act according to their interests. This nursing intervention allows a person to express his feelings sincerely and encourage him to fight for personal rights without violating the rights of others (Lin et al., 2004).

Family psychological education therapy, which is one of the family mental health nursing interventions by providing information and education through therapeutic communication can also help a person who is a member of the family to increase knowledge about illness or health problems along with their psychosocial impact through information and education. Family psychological education therapy can support improved adaptation of a person to health problems and reduce the impact of illness and psychosocial effects on other family members (Townsend, 2009).

Research to determine the effect of assertive training and family psychological education therapy on adolescent self-esteem in preventing drug use in the boarding school has never been done. Therefore, it is important to do research on "the influence of assertive training and family psychological education therapy on adolescent self-esteem in the prevention of drug use in the boarding school." The purpose of this study is to determine the effect of nursing interventions, assertiveness training and family psychological education therapy against adolescent self-esteem in the prevention of drug use in the boarding school.

\section{Method}

This research was conducted using quasi experimental design prepost test with control group. Measurements were made three times, one time before treatment (pre test) and two times after treatment (post test) to assess adolescent self-esteem. In the intervention group 2 was given nursing intervention, assertiveness training and family psychological education therapy, while in the intervention group 1 only got nursing intervention was performed after two post test with the same time span of the intervention group 2 . The instrument used was a questionnaire consisting From 3 questionnaires. Questionnaire A was about respondent's characteristic, questionnaire B was about Drug Abuse Screening Test-20 (DAST-20) questionnaire was used during screening to know adolescents who have never used drug, C questionnaire adopted from Rosenberg Self-esteem Scale (RSES) Measure adolescent self-esteem (Rosenberg, 1965).

The sample in this research is boarding school student's son and daughter who are still actively studying at second grade in boarding school in South Kalimantan. The number of samples in this study were 64 respondents. The sampling technique in this study used purposive sampling to select the sample according to the subjective and practical consideration that the respondent can provide adequate information to answer the research question (Sastroasmoro and Ismael, 2011). In this study, the sample taken based on the criteria of the researcher is a sample with a score of 0-5 criteria from the results of the DAST-20 questionnaire and lived in a house with the family. After that, the sample was selected using cluster random sampling.

This study was conducted for 32 days, with the following meeting details: nursing intervention conducted on 64 respondents on 8 to 11 April 2017 and given nursing intervention each 8 boarding school student per day individually. After that, boarding school students within the intervention group 2 were given assertive training with 5 sessions in groups on 12 to 27 April 2017 after each post test, I. Post test II done after completing 5 sessions for assertive training. On April 12 to May 2, 2017, the afternoon also carried out family psychological education therapy on the boarding school students' family as much as 3 times a meeting with each meeting as much as 1 session and in the last, week conducted session 3. After that done post test II on 3, 4, 6, and May 7, 2017 to see changes in adolescent self-esteem after being given assertiveness training and family psychological education therapy in the intervention group 2. Data processing performed were editing, coding, processing, and cleaning. Analysis of bivariate data using ANOVA repeated measure and independent $t$ test.

Researchers have passed the ethical review test evidenced by a certificate of passing ethical review with No: 52 / UN2.F12.D / HKP.02.04 / 2017. In addition, the researcher has also passed the expert validity test and competency test before doing the research. This study values the basic principles of ethics for respondents: the principle of respecting human dignity, the principle of anonymity and confidentiality, the principle of benefit, harmlessness, and justice.

\section{Results and discussion}

The self-esteem of the boarding school students before and after being given nursing care is found in table 1 .

Based on table 1 it can be seen that the average score of self-esteem of adolescents between before and after nursing intervention changed from 17.92 (high self-esteem) increased to 19.27 (high self-esteem) with a score difference of 1.344 . There was a significant difference between the adolescents' self-esteem score and the adolescents' self-esteem score after the nursing interventions of the intervention group 1 and the intervention group 2 with $\mathrm{p}$ value $=$ 0.007 ( $\mathrm{p}$ value $<0.05$ ).

The self-esteem of the boarding school students' before the intervention (pre) is given, after the nursing intervention (post I), and after assertiveness training and family psychological education therapy (post II) are presented in table 2 .

Adolescent self-esteem in adolescent students of intervention group 2 increased after nursing intervention, Assertive training, and family psychological education therapy from 18.72 (high self-esteem) increased to 21.53 (high self-esteem). Based on these scores can be seen that there is an increase in adolescent self-esteem of 2.81. The result of the analysis showed that there were differences of self-esteem score between the pre test, post test. I and post test II in the intervention group 2 with $\mathrm{p}=0,000(\mathrm{p} \& 0,05)$.

Differences in adolescent self-esteem in adolescents who receive nursing intervention, assertive training, and family psychological education therapies with adolescents who only get nursing care are included in table 3 below. 
Table 1: Effectiveness of Nursing Intervention against Adolescent Self-Esteem in Young Adolescents at Boarding School April - May 2017 (N = 64 People)

\begin{tabular}{lllllll}
\hline Variable & Group & $\mathrm{N}$ & $\begin{array}{l}\text { Mean Before } \\
\text { TKN }\end{array}$ & $\begin{array}{l}\text { Mean After } \\
\text { TKN }\end{array}$ & Mean Deviation & SD Deviation \\
\hline \multirow{2}{*}{ Adolescent Self-es- } & Intervention 1 & 32 & 17,12 & 18,16 & 1,04 & 0,252 \\
teem & Intervention 2 & 32 & 18,72 & 20,38 & 1,656 & 0,268 \\
& Total & 64 & 17,92 & 19,27 & 1,344 & 0,16 \\
\hline
\end{tabular}

Table 2: Effectiveness of Nursing Intervention, Assertive Training, and Family Psychological Education Therapy in Boarding School Students April - May 2017 ( $\mathrm{N}=32$ People)

\begin{tabular}{|c|c|c|c|c|c|c|c|}
\hline \multirow[t]{2}{*}{ Variable } & & \multicolumn{6}{|c|}{ Nursing Intervention, Assertive Training and Family Psychological Education Therapy } \\
\hline & & Mean & Mean Diff. & SD & $\begin{array}{l}95 \% \mathrm{CI} \\
\mathrm{Min}\end{array}$ & Max & $\mathrm{p}$ value \\
\hline \multirow{3}{*}{ Adolescent Self-esteem } & Pre & 18,72 & & 3,448 & 17,476 & 19,962 & \multirow{3}{*}{0,000} \\
\hline & Post I & 20,38 & 2,81 & 3,180 & 19,228 & 21,522 & \\
\hline & Post II & 21,53 & & 3,069 & 20,425 & 22,638 & \\
\hline
\end{tabular}

Table 3: Differences in Adolescent Self-Esteem Rates of Adolescents who Getting Nursing Interventions, Assertive Trainings, and Psychological Education Family Therapy with Boarding School Students who Only Get Nursing Interventions. April - May 2017 (N = 64 People)

\begin{tabular}{|c|c|c|c|c|c|c|c|c|c|}
\hline Variable & Group & Mean & SD & SE Mean & Mean diff. & $\begin{array}{l}95 \% \text { CI } \\
\text { Min }\end{array}$ & Max & $\mathrm{t}$ & $\mathrm{p}$ value \\
\hline \multirow[b]{2}{*}{ Adolescent Self-esteem } & Intervention 1 & 18,88 & 3,129 & 0,553 & \multirow[b]{2}{*}{2,656} & \multirow[b]{2}{*}{1,108} & \multirow[b]{2}{*}{4,205} & \multirow[b]{2}{*}{3,428} & \multirow[b]{2}{*}{0,001} \\
\hline & Intervention 2 & 21,53 & 3,069 & 0,543 & & & & & \\
\hline
\end{tabular}

The average self-esteem score of adolescents in the intervention group 1 who only received nursing intervention that is 18.88 (high self-esteem), while the average adolescents' self-esteem score in the intervention group 2 who received nursing intervention, assertive training, and family psychological education therapy is 21.53 (high self-esteem). The results showed that there were significantly higher self-esteem scores in adolescents who received nursing intervention, assertive training, and family psychological education therapy compared with boarding school students who only received nursing intervention with $\mathrm{p}$ value $=0.001(\mathrm{p}<0.05)$.

Self-esteem in boarding school students at boarding school after getting general nursing intervention, assertive training, and family psychological education therapy increased significantly by $9.37 \%$ and still in high self-esteem category. Assertive trainings given are also aimed to improve the self-esteem of adolescents one of them by training in the second session is to improve adolescent social relationships through the development of social contact ability with parents, peers and other adults. This is in accordance with Keliat, Tololiu, Helena and Erawati (2015) which states that adolescents need close friends to develop social life in achieving the formation of self-concept. Adolescents and close friends can build self-concept and confidence through positive cooperation to build good character.

Kaplan and Sadock (2008) stated that assertive training can be given to individuals with the low self-concept. Self-esteem is a component of self-concept (Lo et al., 2013), so assertiveness training can also be given to adolescents with low self-esteem or for the purpose of increasing self-esteem. The results of this study are also supported by the results of research Kustiawan (2012) which also shows that family psychological education therapy can improve the ability of families to care for client's low self-esteem. A high family ability to care for can improve self-esteem of low self-esteem clients. Family is one social factor that can affect self-esteem in adolescents (Hurlock, 2007). Suerni, Keliat, and Daulima (2013) in his research indicate that a combination of cognitive therapy and family psychological education therapy can lower the signs and symptoms of clients with low self-esteem. Based on the results of this study and supported previous exposure, it can be concluded that the nursing intervention, assertive training, and family psychological education therapy significantly higher can increase self-esteem in adolescent students in boarding schools.

Self-esteem in adolescents who only get general nursing interventions without assertive training and family psychological education therapy increased significantly by $5.86 \%$. This means that adolescents who receive general nursing intervention, Assertive trainings, and family psychological education therapies are significantly greater than those who only get nursing intervention. Therefore, it can be concluded that assertiveness training and family psychological education therapy has more influence on the self-esteem of boarding school students so it can be applied for nursing specialist mental health nursing in giving nursing intervention to the adolescent group.

\section{Conclusion}

Conclusions in this study that there has an effect on the effectiveness of nursing interventions, assertive training, and family psychological education therapy against adolescent self-esteem in the prevention of drug use in boarding school. Nursing interventions, assertiveness training, and family psychological education therapy can increase adolescent self-esteem in preventing drug use in boarding schools.

\section{Acknowledgments}

Acknowledgments are given to the PITTA Grants 2017 grant from the University of Indonesia's Directorate of Research and Community Service (DRPM) team to assist with the international publication of the students' final assignment in order to increase the quantity and quality of international publication.

\section{References}

[1] Asia, N. (2008) Hubunganantarahargadiridanasertivitasdenganperilakuprososialremaja. Skripsi. Surakarta. FakultasPsikologiUniversitasMuhammadiyah Surakarta.

[2] BNN RI. (2015). Laporan Kinerja Badan Narkotika Nasional Tahun 2015.

[3] Hanana, N. F. (2015).Pengaruh Self-Esteem dan Kecerdasan Emosi terhadap Perilaku Prososial pada Santri Pondok Pesantren Daarul Rahman Jakarta. Skripsi. Jakarta: Fakultas Psikologi, Universitas Islam Negeri (UIN) Syarif Hidayatullah.

[4] Hurlock, E. B. (2010). Psikologi Perkembangan: Suatu Pendekatan Sepanjang Rentang Kehidupan (Alih Bahasa Istiwidayanti, dkk). Edisi Kelima. Jakarta: Erlangga.

[5] Kaplan, H. I. \& Saddock, B. J. (2005). Sinopsis Psikiatri (8th ed). Jakarta: Bina Rupa Aksara.

[6] Keliat, B. A., Tololiu A. T., Daulima, N. H. C., \& Erawati, E. (2015). Effectiveness Assertive Training of Bullying Prevention among Adolescents in West Java Indonesia. International Journal of Nursing, 2(1), 128-134. https://doi.org/10.15640/ijn.v2n1a14.

[7] Khajehdaluee, M., Zavar, A., Alidoust, M., \& Pourandi, R. (2013). The Relation of Self-Esteem and Illegal Drug Usage in High School Students. Iran Red Cres Med J, 15(11). https://doi.org/10.5812/ircmj.7682. 
[8] Kustiawan R. (2012). Pengaruh Terapi Psikoedukasi Keluarga Terhadap Kemampuan Keluarga Merawat Klien Harga Diri Rendah di Kota Tasikmalaya. Tesis. Depok: FIK-UI.

[9] Lin, Y.-R., Shiah, I.-S., Chang, Y.-C., Lai, T.-J., Wang, K.-Y., \& Chou, K.-R. (2004). Evaluation of an assertiveness training program on nursing and medical students' assertiveness, self-esteem, and interpersonal communication satisfaction. Nurse Education Today, 24(8), 656-65. https://doi.org/10.1016/j.nedt.2004.09.004.

[10] Cascio, V. L., Guzzo, G., Pace, F., Pace, U. (2013). Anxiety and selfesteem as mediators of the relation between family communication and indecisiveness in adolescence. Int $\mathbf{J}$ Educ Vocat Guidance, 13 135-149. https://doi.org/10.1007/s10775-013-9243-1.

[11] Pusdatin Kemenkes, RI. (2014). Tahun Penyelamatan Penguna Narkoba. Buletin Jendela Data Dan Informasi Kementrian Kesehatan Republik Indonesia. ISSN 2088-270X.

[12] Pusdatin Kemenkes, RI. (2015). Situasi Kesehatan Reproduksi Remaja. ISSN 2442-7659.

[13] Rosenberg, M. (1965). Society and the adolescent self-image.Princeton, NJ: Princeton University Press. https://doi.org/10.1515/9781400876136.

[14] Sastroasmoro \& Ismael S. (2011). Dasar-dasar Metodologi Penelitian Klinis. Edisi 4. Jakarta: Sagung Seto.

[15] Stuart, G. W. (2013). Principles and Practice of Psychiatric nursing (10th ed). St. Louis: Mosby Elsevier.

[16] Suerni, T, Keliat, B. A., \& Daulima, N. H. C. (2013). Penerapan Terapi Kognitif dan Psikoedukasi Keluarga pada Klien Harga Diri Rendah di Ruang Yudistira Rumah Sakit Dr. H. Marzoeki Mahdi Bogor Tahun 2013. Jurnal Keperawatan Jiwa . Vol. 1, No. 2; 161-169.

[17] Sulistyowati, W. \& Warsito, H. (2010). Penerapan konseling realita untuk meningkatkan harga diri remaja. Jurnal Psikologi Pendidikan dan Ilmiah, 2(1). Diunduh dari: http://ejournal.unesa.ac.id/index.php/jurnal_ppb/article/view/5407/7906

[18] Swenson, R. R. \& Prelow, H. M. (2005). Ethnic identity, self esteem, and perceived efficacy as mediator of the relation of supportive parenting to psychosocial outcomes among urban adolescents. Journal Of Adolescence. (28), 465-477. https://doi.org/10.1016/j.adolescence.2004.09.005.

[19] Townsend, M. C. (2009) Psychiatric mental health Nursing Concepts of care in Evidance-based Practice. Philadelphia: F. A Davis Company.

[20] Widodo, A. (2009). Peningkatan Keterampilan Pencegahan Perilaku Penyalahgunaan Narkoba Bagi Remaja Di Desa Gonilan Sukoharjo, 12(1), 15-24. 